\title{
Statement by Miguel de Serpa Soares
}

\author{
Under-Secretary-General for Legal Affairs and United Nations \\ Legal Counsel
}

On behalf of the Secretary-General, I am delighted to be with you in Geneva for this commemorative meeting marking the seventieth session of the International Law Commission.

It is pleasing to see many legal advisers in the audience, as well as present and former members of the International Law Commission, academics, and representatives from regional bodies and other organizations. An occasion like this presents us with an opportunity to honour the International Law Commission and to exchange thoughts, insights and ideas on its past achievements and future challenges. I encourage all of us to actively participate in the discussions.

During the earlier commemoration in New York, on 21 May, I recalled that the Commission held its first session in Lake Success, New York, in 1949. On this occasion, it seems appropriate to add that the Commission's predecessor met here, at the Palais des Nations in Geneva, 25 years earlier. On 12 December 1924 , in the room that we are meeting in today, the Council of the League of Nations established the "Committee for the Progressive Codification of International Law". The Committee consisted of 17 experts in international law and was tasked to identify questions that were "sufficiently ripe" for codification.

Similar to the Commission, the members of the Committee served in their personal capacity and, as a whole, represented the main forms of civilization and the principal legal systems of the world. It comprised many noted international lawyers of the day, such as José Gustavo Guerrero, from El Salvador, who later served as the last President of the Permanent Court of International Justice and the first President of the International Court of Justice; Simon Rundstein, the Polish expert on judicial and arbitral procedure; and a young professor from the United Kingdom, James Brierly, who was later elected as one of the first members of the International Law Commission in 1948. With him, the baton of excellence, study and reflection was passed on to the next generation of international lawyers.

With this commemorative meeting today, we not only pay tribute to the achievements of the International Law Commission in the past 70 years; we also honour the efforts of those who laboured towards the ideal of the progressive development and codification of international law prior to the Commission's establishment. 
Over the years, Geneva has remained at the heart of the codification effort. The successes of the International Law Commission over seven decades can be ascribed, in part, to the unrivalled facilities, library and surroundings of the Palais des Nations, as well as the generous hospitality of our Swiss hosts. At a distance, though not isolated, from the dynamics in New York, Geneva has proven highly conducive for serious study of and debate on complex questions of international law. It is only fitting that the Commission retains its seat here, where the first organized international efforts to codify and progressively develop international law started almost a century ago.

At the very first session of the Commission, in 1949, my erstwhile predecessor Ivan Kerno said the following: "International law is like a great and ancient edifice the doors of which are being opened so that it can ... serve as a shelter to mankind. Only under its protective roof can the Members of the United Nations find the international peace which the Organization has been established to ensure and maintain." These words still hold true. The framers of the Charter of the United Nations affirmed the central role of international law in the architecture of peaceful relations between States, and more than seven decades later this role has not changed. The International Law Commission remains at the centre of the development and strengthening of the international legal order. As we reflect further on what our Commission can do, I can only affirm the continuing relevance of international law, and express the conviction that it will continue to provide a shelter to mankind in future years. Let me conclude by wishing us all a fruitful and inspiring two days.

1 ILC, 'Summary Record of the 1st meeting' (1949) UN Doc A/CN.4/SR.1, 9 at para 10. 